Int. J. Dev. Biol. 58: 79-86 (2014)

doi: $10.1387 / \mathrm{ijdb} .130332$ st

\title{
A lifetime of deciphering complexities of embryo implantation
}

\author{
SUSANNE TRANGUCH ${ }^{*, 1}$ and SUDHANSU K. DEY² \\ ${ }^{1}$ Office of Science and Research, New York University Langone Medical Center, New York, NY and \\ ${ }^{2}$ Division of Reproductive Sciences, Perinatal Institute, Cincinnati Children's Research foundation, Cincinnati, Ohio, USA
}

\begin{abstract}
This interview chronicles the story of Sudhansu K. Dey in his journey from Calcutta, India to Kansas City, Kansas, establishing a research enterprise in the field of female reproduction. His research of over four decades has focused specifically on implantation biology using various model systems and reveling the impact of implantation on female reproductive medicine. This interview also reveals qualities of SK's character - his resolution, mentoring spirit, and humble nature - that contributed to his successes. SK is not shy to approach individuals for expertise or help, and in the same spirit, he is ready to offer his help to others irrespective of their positions or stature. He constantly attributes his success to the hard work of his laboratory members, the intellectual stimulation from his collaborators, and the support from his family. His ability to overcome challenges throughout his career is a reminder to students and junior investigators in the scientific community that each individual is endowed with talents and can accomplish their dreams if they pursue them. This interview tells the story of how he progressed from an inquisitive child to becoming a true servant to the cause of science and humankind.
\end{abstract}

KEY WORDS: implantation, pregnancy, embryo, uterus, estrogen

If there is one scientist that should write a book about his life, it is Sudhansu K. Dey, known to all as SK. How a man became such a success after journeying to America with only $\$ 7$ to his name is a testament to his passion and determination. Anyone that meets him will bear witness to his ability to inspire curiosity; when I joined his laboratory, I was tasked with coming up with an idea every morning - not just about implantation or pregnancy events, but about anything that caused me to ask 'why'. SK lives by example; he is the first to make himself available for advice, is always willing to share resources (including to competing labs), and constantly figures out ways to allow himself to learn. From the day I joined his lab, I found myself arriving by 6 am, 7 days a week - each day beginning with a cup of coffee with SK, sometimes a short walk around the Vanderbilt campus, and always a discussion, scientific or otherwise. Throughout my graduate career, he showed me the dedication required to become a successful scientist, the hardships associated with this career path, and the reward that comes with advancing science. I certainly learned ample science from this man, but I also learned the value of curiosity and humility, how to be a hard worker, how to push myself, and how to inspire others to do the same. I am a better scientist and a better person for having trained in his lab, and his mentorship continues to this day with our (not 6 am thankfully) phone conversations.

I interviewed SK in November 2013, a few days before his birthday. He allowed me to call in the 'afternoon', which in the language of SK - a man who wakes up at 3am - means around 8 am. Our conversation evoked reflection and nostalgia for my days in his lab at Vanderbilt, with us both reminiscing how terrified I was when I initially joined. I had heard rumors of SK's demands for high quality, for hard work (from Yvette Huet with whom I was doing my Master's thesis).... and I was so terrified that I wouldn't live up to his expectations that I literally passed out two or three times during those first weeks. SK certainly surpassed my expectations for a graduate student mentor. In interviewing SK for this article, I hope I can communicate his wisdom and character, so that through his words and experiences, we can all learn something and even more, see the world through his eyes - full of wondrous science and awesome potential.

You were raised and educated in India. How did these experiences influence your pursuit of a career in science?

My parents told me that if you want to be successful in life, you

Abbreviations used in this paper: SK, Sudhansu K. Dey.

\footnotetext{
*Address correspondence to: Susanne Tranguch. Office of Science and Research, NewYork University Langone Medical Center, 1 Park Avenue, 6-208, New York, NY 10016, USA. E-mail: susanne.tranguch@ nyumc.org
}

Final, author-corrected PDF published online: 8 July 2014

ISSN: Online 1696-3547, Print 0214-6282 
must be honest, sincere, and pursue your dreams to the fullest extent. I am the youngest of 12 children, and regardless of our income, they were always encouraging us. I was raised in the outskirts of Calcutta, which was predominantly a farming community, so I was surrounded by lots of nature - fishing ponds, fields, etc. We often struggled to put food on the table, so I helped by growing vegetables, raising chickens and breeding goats, cows, and pigeons. I became intrigued by the feather colors of pigeons (how do they develop? how are they aligned?) and by the breeding strategies of various animals. I became quite expert in delivering calves from cows undergoing difficult labor to the point where neighbors would call me to help deliver their cows. Being in nature inspired a curiosity in me - I began fishing, watching birds, wondering how differences in reproduction strategies occur to sustain each animal population. I found that I had a natural knack for answering these questions l'd go catch a frog, dissect the lung, and puncture it to analyze its contents and figure out how the lung collapses. This environment instilled my deep passion for nature and basic science research. Instead of mitigating the symptoms of difficult labor, how can we determine the root cause and the underlying biology?

At Presidency's College, I was really inspired by two professors: Professors Debajyoti Das and Prafulla Karmaker. This is when I really learned biology and excelled in physiology. When I joined the PhD program at Calcutta University, my mentor was Dr. Mrityunjoy Mukherjee. Somehow he had heard about me while I was doing my Master's and thought I would be a good fit for his laboratory. He was brilliant - in his 30s, already with his PhD and DSc. I joined his lab and whenever I came to work, he wanted to chat. He told me that anyone can get a degree being in a lab and spending a few years doing benchwork, but that I would learn more from chatting. Dr. Mukherjee passed away 6 months after I joined his laboratory, but in those 6 months, he definitively developed my passion for science.

When SK said this in our interview, it made me smile. I can see how Dr. Mukherjee influenced SK's own style of mentoring. There were so many times when I had to tell SK - I have to go to the animal room now, I can't chat with you all morning. Dr. Mukherjee and SK were both correct. I think we both learned more than we knew from these morning conversations.

My elder brother P. K. Dey was another influence, as he was a neurophysiologist in basic science; his career and my parents' support contributed to the environment that instilled and directed my scientific behavior.

When did you become interested in reproductive biology and more specifically embryo implantation research?

When I was growing up in India, the population growth was exploding and plaguing society with financial burden and anxiety. People were starving, famine abounded, and I was very idealistic. I wanted to do something good for our country. Perhaps I could address population growth by searching for novel approaches to restrict it by understanding reproductive processes.

After Dr. Mukjerkee passed away, I didn't have any supervisor or fellowships, and I joined the laboratory of Dr. C.C. Deb, who provided a small stipend. His laid-back nature perhaps inspired his decision that if I did my research independently, I could join his lab. This may have been one of the best things to happen in my life - during this time, I became so independent, figuring out ways to seek reagents and help from others. To conduct research with such low funding, I would raise and house rats at my home and catch toads and fish for comparative reproductive physiology experiments. Still, I was able to train junior graduate students and ultimately published numerous papers in journals outside of India. I focused my research initially on both female and male reproduction, publishing two papers - one on the uterus during early pregnancy and one on the testis - in the Journal of Reproduction and Fertility (Sen Gupta et al., 1973; Dey et al., 1973), which was the flagship reproduction journal at the time. Prior to publication, I received a bill of 20 pounds for figure charges. I wrote to Sir Alan S. Parkes, the editor in chief, that I didn't have any money to afford this charge. He wrote back (by snail mail of course) that the fee was waived. I was so grateful. My salary at the time was 300 rupees per month (for perspective, today 20 pounds would equal 1971 rupees).

In one of our chats, Dr. Mukjerkee explained his brilliant idea that glycogen moves from the base to the apex of the luminal epithelium during implantation. Here, glycogen gets broken down and is converted to other energy products to nourish the growth of the embryo for its implantation. To break this conversion, I used sodium malonate to block the TCAcycle in pregnant rats, but observed that reproduction actually improved. I was so intrigued by this, so I went to the library and researched through huge volumes of biological abstracts. I found a paper showing that if you block the TCA cycle, carbohydrate metabolism can be shunted through the pentose phosphate pathway, generating NADPH, which is a cofactor for steroidogenesis. I did not have access to measure steroid levels, but I took several other approaches to test this hypothesis. Today, increasing numbers of studies describe metabolic pathways and their roles during early pregnancy.

During my PhD training, I established my routine that I maintain even now. I would take the $1^{\text {st }}$ bus to the lab ( $\left.6 \mathrm{am}\right)$ and return on the last bus. I was determined to accelerate discoveries in this field. If I could block implantation, perhaps I could help find a solution to the population growth in India.

\section{What was your rationale for pursuing postdoctoral training in the United States and at the University of Kansas?}

In looking for potential post-doctoral fellowship opportunities in reproduction-focused laboratories, I didn't have any particular affinity for coming to the US; I applied to Australia, UK, US, and some Scandinavian countries. Responses from several institutions were the same - funding was low, so they were not accepting positions (perhaps a polite way of rejection?). In the US, Johns Hopkins had an opportunity in the Surgery Department, and University of Kansas had a Ford Foundation funded fellowship position in reproduction. At the time, Kansas was at the forefront of reproductive biology, housing Dr. Gilbert Greenwald, Dr. Donald Johnson and several other reproductive biologists. I was assigned to work in Dr. Zeev Dickman's laboratory, with a relatively a small stipend. My son had just been born, so I accepted this opportunity.

Jim Hurt was the technician in Dr. Dickman's lab and an expert in preimplantation embryo manipulation and embryo transfer. He had tremendous hands. I realized that if I could keep him happy, I would be able to learn so much. l'd make him coffee or tea and would wash his dishes; in return, he would sit in his chair, smoke his cigar, and show me all his tricks. I became an expert in these techniques; I would often come to the lab around 3 am and stay after hours, practicing these techniques. He taught me the importance 

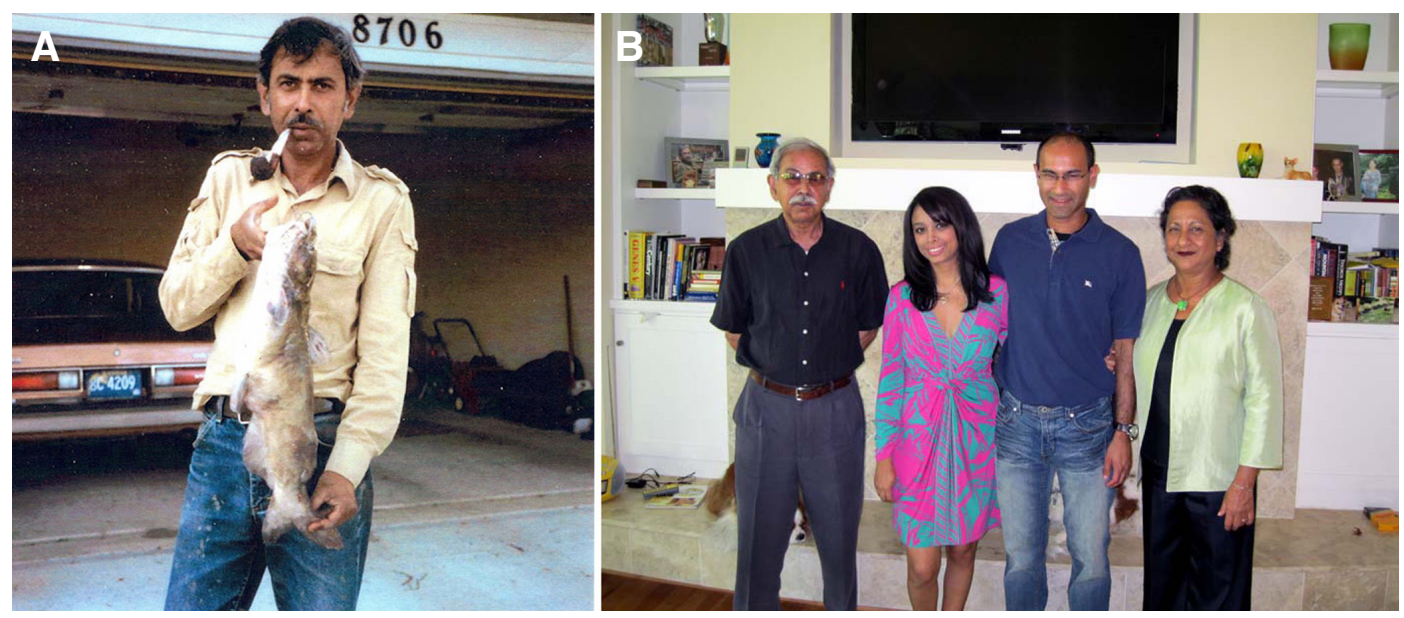

Fig. 1. The fisherman $(A)$ and the scientist with his family (B). From left to right: SK, Mahua (daughterin-law), Maruti (son), Anjana (wife) and the dogs (peeping from behind).

of learning from anyone, regardless of title. Some people have a tremendous ego, which ultimately prevents them from taking advantage of learning opportunities.

During this time, I encountered many adverse situations that often come during a postdoctoral fellowship. I used these situations to my advantage. I value the relationships and collaborations encountered during this time, particularly Dr. Bob Crist, an MD/ PhD clinician, who had ample sources of clinical funding and resources, who provided a refuge to work in his lab; ultimately, we also published together.

After completing your postdoctoral training, you joined the faculty at the University of Kansas and remained there for the next $\mathbf{3 0}$ years. How did your experience at Kansas shape your scientific career?

Kansas University Medical Center is truly my second home. All of my major research experiences and initiatives matured and were realized at KUMC. Although my initial years were rocky and unpredictable, often with fear of defeat and doom, my strength and determination weathered me through those difficult times. I truly believed that failure was not an option. Throughout my thirty years there, I immensely enjoyed my research activities and was blessed with so many bright and young investigators.

My initial recruitment was possible because of Kermit Krantz, Chairman of OB/GYN, and again, Bob Crist. Kermit recognized the importance of a competitive basic research program in developing a strong university and was intent on recruiting bright PhDs and MD/PhDs. In line with his mission, he told researchers they did not have to attend faculty meetings that focused on clinical issues, so they could spend focused time developing their research programs.

At the time, I was packed up and ready to return to India, because I was no longer interested in being a postdoctoral fellow. I told Kermit of my plans, he said okay you are hired as a faculty, and his secretary typed my offer letter right there. I already had my ticket to Europe and India, and he said ok, go on vacation, and then come back. So Anjana (my wife), Maruti (my son), and I went to Europe, with my family continuing to India. In Europe, I visited Anne McLaren's lab in London, UK, Ove Nilsson's lab in Uppsala, Sweden, and the WHO in Geneva, and then met up with my family in India. I then returned to my new lab in KUMC, which was an empty room with some glass cylinders, and the warning that if I didn't get a grant within one year, l'd be fired. I had no start-up funds and no other tools than these glass cylinders. So, I started writing grants right away. Perhaps this was the best mentoring -1 was terrified but remained resilient.

With the task to obtain a grant looming, I worked with Dr. Don Johnson and other investigators to gather preliminary data. Later, Dr. Billy Hudson (Dean of research at the time) gave me $\$ 3,000$ to buy supplies and a few animals. He saw that I was confident and determined to survive. Drs. Johnson and Greenwald were also so valuable in shaping my research outlook and career path at that time. Dr. Johnson opened his lab to me, offering any of his resources, reagents, and space. I submitted two grants that first year - one was funded on the $1^{\text {st }}$ submission (the role of histamine and phospholipase A2 derived prostaglandins in implantation). I came up with this idea reading a Nature issue; the other grant took 4 times to get funded and was the most innovative (catecholestrogen and implantation). After the $3^{\text {rd }}$ rejection, I requested a site visit by the NIH Study Section and as soon as that happened, the grant was funded. Catecholestrogens were not a favorite topic at the time - it was difficult to work with since its half-life was only a few minutes. I had always thought - why does implantation require so much progesterone $(\mu \mathrm{g})$ but so little estrogen $(\mathrm{pg})$, even though their binding kinetics to their respective nuclear receptors appear more or less similar? My grant predicted that catecholestrogen is produced locally, either in the uterus at the site of implantation or in the activated blastocyst, to initiate implantation and then just as quickly, disappear.

In the pig, we found that catecholestrogen is a major steroid product in the blastocyst (Mondschein et al., 1985). Because of the much smaller size, it is harder to show catecholestrogen's presence in the mouse blastocyst, especially with the available technology at the time. We later used microarray analysis to compare gene expression profiles at the implantation versus inter-implantation sites, and found that the catecholestrogen producing enzyme, CYP1B1, was expressed at lower levels in the implantation versus inter-implantation site, suggesting that catecholestrogens generated at the vicinity of the blastocyst influence implantation (Reese et al., 2001). Our in situ hybridization results confirmed its disappearance from the implantation chamber and its presence in the inter-implantation sites. I had that grant for $>5$ years, and my former post-doc Dr. Yasushi Hirota is now interested in reviving the project in human studies.

I should say that all of my successes (if any) in the lab are be- 


\begin{abstract}
Fig. 2. Early years in Kansas - individuals who influenced SK's career path. (A) Donald C. Johnson (mentor, colleague and friend) with his wife Eleanor, (B) Ansley Spencer (dish washing to scientific editing), and (C) Glen Andrews (collaborator, friend, and fishing buddy).
\end{abstract}
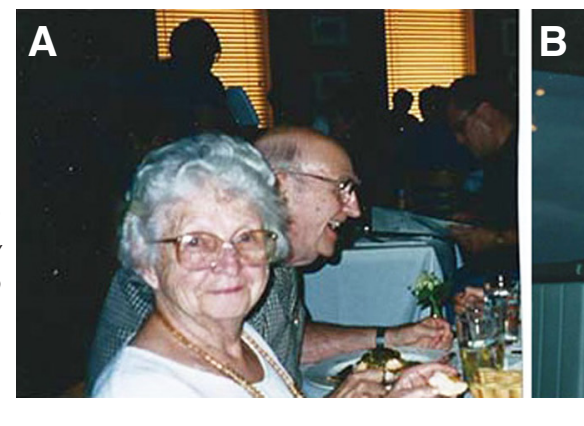

cause Anjana, my wife, took care of the home - household chores, raising our only son Maruti - basically as a single parent (Fig. 1). I would leave for the lab at 3:30 am, come home, eat, and go back, and she never complained. She is the same way now, still taking care of most, if not all, things at home. Also, Maruti grew up knowing the value of hard work and sacrifice. He understood my devotion to research and supported me.

During the initial stages of my faculty position, I didn't have any help - not until I secured that first grant. After that, I published a paper in Nature (Dey et al., 1979), which seemed to instigate increased funding. My $1^{\text {st }}$ MERIT award from NICHD/NIH came in Kansas, and I was ultimately given a distinguished professorship title. Although there were certainly rough times, there were also some people that were so helpful opening their doors to me during those early years - those people all became and remain quite close friends. Specifically I would like to acknowledge my close and long collaboration with Glen Andrews and my experience working with Ansley Spencer, who showed true dedication to my lab (Figs. 2 and 3). As a high school student, she started as a glass washer in the lab and gradually became very devoted to helping me in grant writing and editing. Her premature death in a car accident a few years after her marriage still saddens my family and others who knew her.

You subsequently moved your laboratory to Vanderbilt University and more recently to Cincinnati Children's Hospital Medical Center. How have these scientific environments influenced research in your laboratory?

Although the process of moving is painful, the advantage is that every place I moved, I acquired new expertise and colleagues. After 30 years at Kansas, I needed new avenues. While at Kansas, I was reading an article about development, specifically how bird feathers were arranged and how bone morphogenetic protein (BMP) might play a role in this process. I called Brigid Hogan, then at Vanderbilt, and I discussed this paper with her, told her how embryo implantation is nicely spaced, and questioned whether BMP could play a role here as well. She offered me all her BMP tools and reagents, and we started collaborating, ultimately publishing work on BMP and Indian hedgehog $(\mathrm{IHH})$, work published in Developmental Biology and Proceedings of the National Academy of Sciences (Paria et al., 2001; Matsumoto et al., 2002). I also met Ray DuBois, who was also at Vanderbilt at the time, and working on Cox2; my interest was also in Cox2's role in implantation. They both encouraged me to come to Vanderbilt. I also thought - why not join this university? Brigid approached Dr. Arnie Strauss, new chairman of Pediatrics, to recruit me.

Moving to Vanderbilt was marked by good news of receiving the 2nd MERIT Award from NIDA/NIH for our work on endocannabinoid signaling in early pregnancy. At Vanderbilt, I formed collaborations
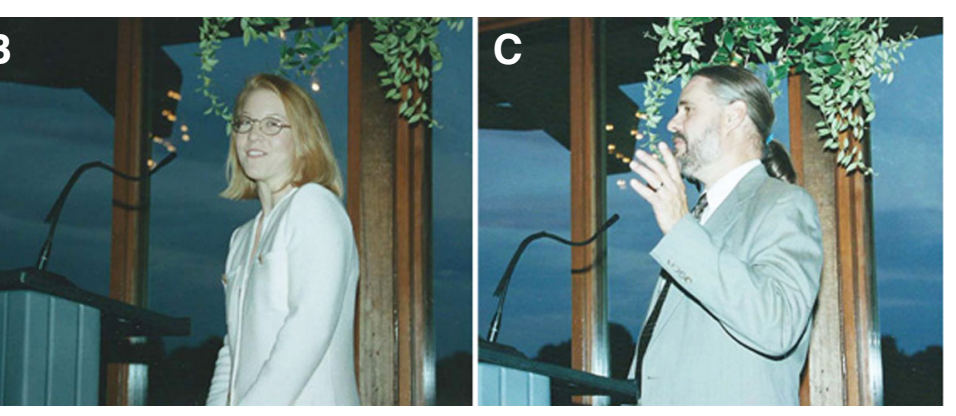

and met wonderful people: Ray DuBois, Richard Caprioli, Lila Solnica-Krezel, Chin Chen, Larry Marnett, Jason Morrow, David Greenstein, Bob Collins, Mike Waterman, and many others (Fig. 4). These new perspectives allowed my research to forge new avenues - proteomics and in situ proteomics with Caprioli's lab, Cox2/Prostaglandin research with Ray DuBois and Jason Morrow, and reinstating the reproductive biology training grant with David Greenstein and a PO1 grant with Ray, which resulted in several collaborative publications. Here I also learned that if any university wants to run a successful graduate program, Roger Chalkley is the person you want to meet. My Vanderbilt connection continues, as I collaborate in proteomics with Kristin Burnum at Pacific Northwest National Laboratory; she was Richard Caprioli's graduate student and worked closely with Susanne Tranguch in the lab.

Unfortunately, a leadership change associated with changes in their animal care services became an issue; it was more difficult to get protocols approved, and with more than 60 strains of mice and my research program relying heavily on mouse models, I made the decision to join Cincinnati Children's, encouraged by Arnie Strauss who had also left Vanderbilt earlier to become the head of Cincinnati Children's. This desire was reinforced because, among others, Brigid and Ray had also left Nashville by then. It was difficult for Anjana to leave Nashville, since she is a musician and loved the music scene there but again, she sacrificed for the pursuit of my research.

In Cincinnati, I started a new division, which comes with its own challenges, but again, the new colleagues and collaborations make these challenges worthwhile (Fig. 5). Individuals like Chris Wylie, Janet Heasman-Wylie, Jeff Whitsett, Steve Potter, and Stuart Handwerger to name a few, from whom I learned new things. Gary Keller, the director of animal care here, is the best director l've ever worked with, and that makes a huge difference to my operation as a researcher. I have always enjoyed interacting with new members in the lab too - honestly, in every lab, there can be 7-8 people, but it's always a handful of people that work harder and tend to carry the lab.

\section{Science is a challenging occupation. Did you experience any obstacles in your career and how did you navigate through any difficulties?}

I experience struggle every day from many aspects - capturing grant funding, maintaining productivity in the lab, finding good people for the lab, making the decision to let go of non-productive ones (always a challenging task), dealing with space problems; also, running a division is quite demanding from a human factor perspective-dealing with administrators, with different personalities in faculty, with different people having different needs and demands. It's always a challenge. I try to handle problems right away as much as I can. I try to work hard and efficiently, and anticipate problems, to see what is coming. 
I have never been very happy in the true sense, mainly because I think I can always do better and I always thought that my job was not secure. I demand high quality from everybody, including myself. But I have been very fortunate to have had talented individuals to maintain my lab's productivity at a high level.

Science is all about interacting and learning from colleagues. Are there colleagues that you considered as mentors who helped guide you in your career?

Like I mentioned earlier, my first supervisor, Dr. Mukjerkee, taught me the beauty of science and how to enjoy it. Dr. Deb, my second mentor, let me be independent, which was quite a valuable lesson. Other valuable mentors include my two professors from University, Professors Das and Kamaker in Calcutta; Brigid Hogan; Don Johnson; Alexandre Psychoyos; Koji Yoshinaga; Allen Enders; Rodney Mead, Bruce Murphy; and others.

All my graduate students have been my mentors - they keep me honest and focused: Yvette Huet-Hudson, Karen Kover, Jade Lim, Haengseok Song, Susanne Tranguch, Xiaofei Sun and Jeeyeon Cha - some more productive, some more interesting characters... but from all of them, I experienced something new, and they are all very helpful. When your graduate students are good, they demand more from you, which requires you to shape your career. Who wants to look terrible in front of their brilliant graduate students? Also I had also been fortunate to have great postdoctoral fellows in my lab through years; to name a few, Sanjoy Das, BC Paria, Takiko Daikoku, Hiromichi Tamada, Hiromich Matsumoto, Hiurong Xie, Haibin Wang and Yasushi Hirota. More amazingly, I had some exceptional research staff....Esther Hope, Wen-ge Ma, Jian Tan, Xuemei Zhao, Amanda Bartos, Yingju Li and others.

\section{Who were your role models in science?}

Some of the people who played a huge role in my scientific outlook were Don Johnson, who had so much love for science and would help anyone at any time; Aleko Psychoyos and Koji Yoshinaga, very

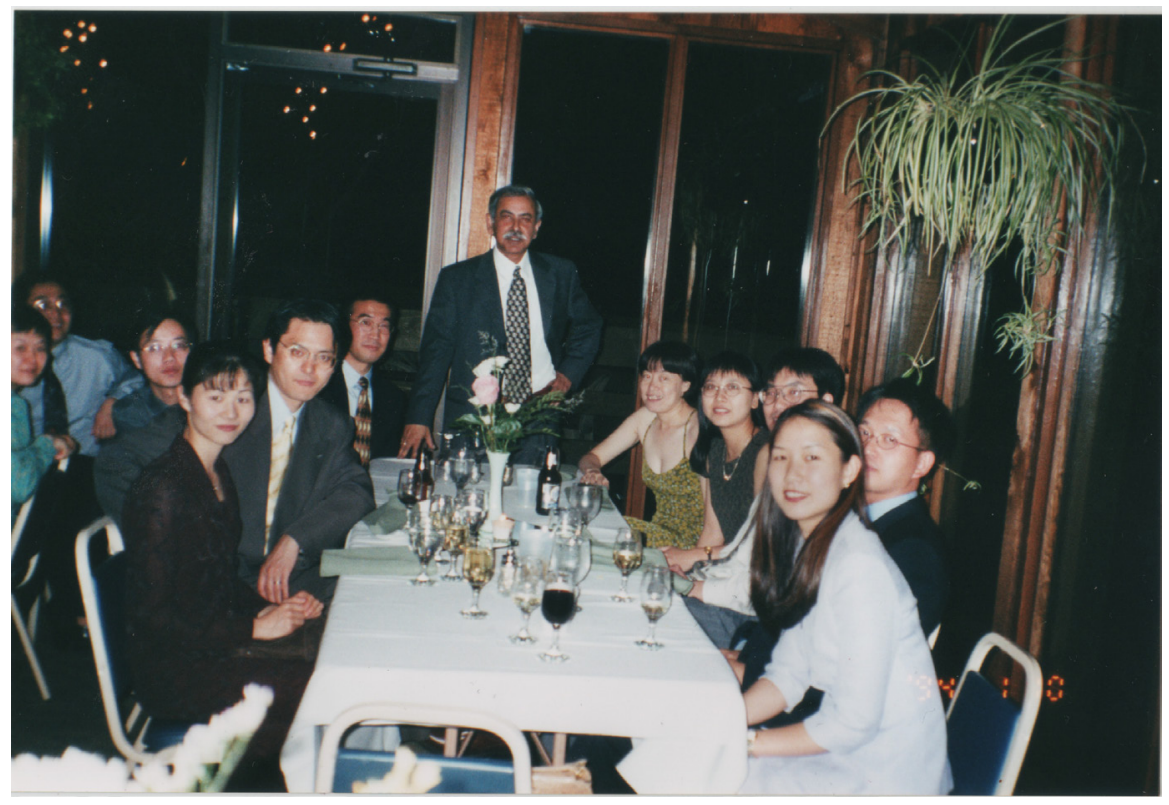

Fig. 3. Gathering of young and bright minds in Kansas. Lab members at the wedding reception of Maruti (son) and Mahua. good friends, who really helped me understand uterine receptivity; Anne McLaren; and Stanley Cohen, who used simple approaches to answer profound questions in biology. It is difficult to find these kinds of people.

You have trained a number of scientists that have gone on to have productive careers. What is your philosophy for training students and fellows?

I always tell my students that pursuing research is not a hobby or job; it's a passion. It's a hard difficult road, but addictive and beautiful. Some people listen, and others don't. Some people take this advice and work so hard - you have to feel from the pull of your heart that you must pursue science, no matter how difficult it is. You can't replace the joy of knowing the unknown with money - it's a different kind of joy. I was a full professor making \$ $36 \mathrm{k}$ - it would have been nice to have more money, but I could never quit my work routine and I never complained.

I demand hard work and absolute honesty from people - I always remind everyone that curiosity and imagination are the drivers for answering unsolved problems - this leads to new knowledge and discoveries, which leads to more curiosity, perpetuating the cycle. I also remind people that sincerity and honesty in scientific pursuits is most important. As many of my trainees will hear me say: "I'd rather be poor than ignorant and slimy."

[S. Tranguch: I used to save quotes from SK and stick them on my bench. This was always one of my favorites.]

\section{What characteristics and skill sets are the most important for a successful scientist?}

I've always been tough, but I'm also always honest. A scientist should be hardworking, have a good attitude, celebrate successes quietly, and take defeat as a learning process towards success. Also, never say something is impossible or you can't do it - if I pick up the phone, I can solve it.

I can't tolerate research looking at things going up and down. Always ask hard questions. You need tremendous people skills. Try to stay away from politics. Stay away from aspiring to be academy members, or get this or that award - just focus on your work, and if it comes, it comes.

[S. Tranguch:SK teaches the importance of these skills to all his trainees. Not only is he incredibly loyal to his students, but he is also supportive, and yes, tough. One of the most valuable lessons he taught me was to never compare myself to others; only compare yourself to whether you can be better, and whether you have given your best. I have reminded myself of this countless times, and it has inspired me each time to work harder and pursue more difficult challenges. Whether someone else succeeds is not a reflection on my success; we each determine our own path.]

During your career, you have been part of several productive collaborations. What are the keys for a successful collaboration?

Don't hesitate to ask for help or provide help - regardless of who it is or what position they have. Give more than you ask for. Deliver on 
your promises. If you make a promise, do it, and be persistent in pursuing the cause - build mutual trust and respect.

\section{What are your proudest accomplishments as a scientist?}

This is a difficult question, as there is no single one-my pride is when I see my graduate students and post docs thriving in science or in their lives, when they receive awards or competitive grants, or secure coveted positions.

[S. Tranguch: When I told SK about my recent promotion, I could feel his excitement through the phone. I emailed him afterwards to thank him for all he had done for me and told him that I wouldn't have been so successful, becoming an editor at Cell Press and securing this position at NYULMC without his influence. He wrote me back and said "Remember each individual is responsible for his or her career. It is you who made this possible." I saved that email and have it in my office.]

Perhaps my proudest moment in life was telling my mother that I was going to receive my PhD. My mother had suffered from a cerebral stroke and had been paralyzed for 15 years. She always used to ask me when I was going to get my PhD. The day I appeared for my oral defense, the committee was asking me crazy questions that weren't related to my project. Soon, they realized I was with the wrong defense team! Once I faced the right committee, I answered their questions and returned home to tell her that yes, I was going to pass and receive my PhD. She was so happy, and within a few days, she passed away, knowing that I would one day have my own lab and research program.

Mouse models have had a tremendous impact on our understanding of the molecular network regulating embryo implantation. Will the mouse continue to be the workhorse for discovery in embryo implantation research?

Mouse models will still be useful for mechanistic understanding of implantation, but studies on other animal models should still be used (rabbits, non-human primates, large animals) to provide a better framework. For example, cows, sheep and pigs have no typical decidua, while hamsters, guinea pigs, and rabbits don't need

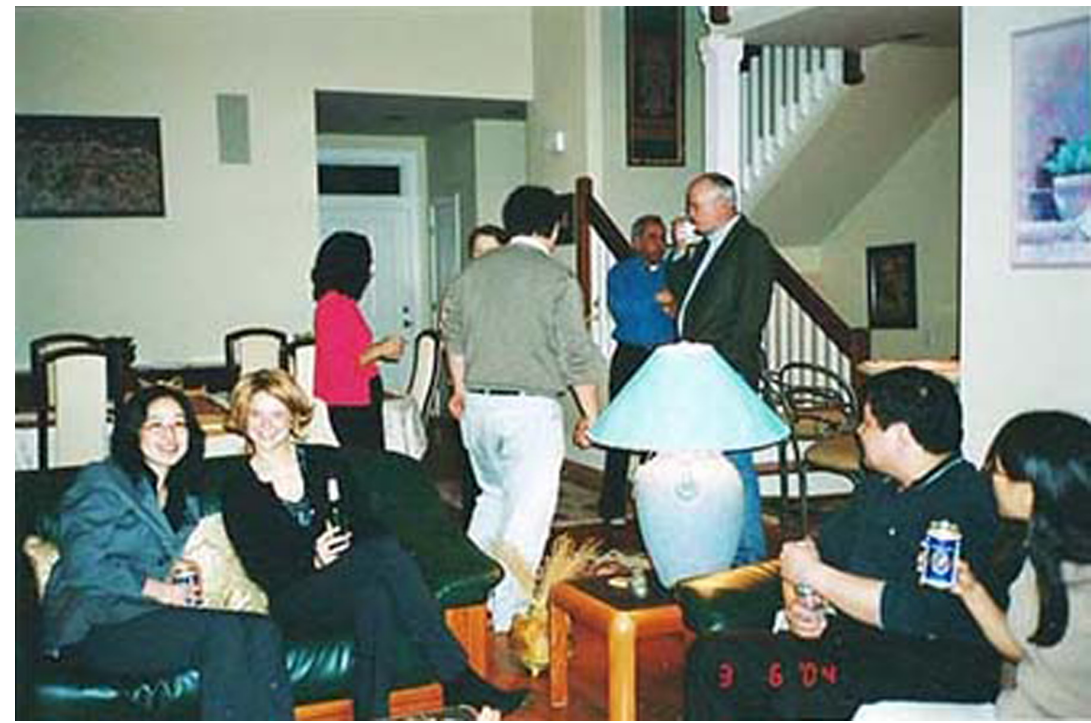

Fig. 4. A party in SK's Nashville home. A mix of young and senior scientists, including the interviewer Susanne Tranguch, second from left on couch and Ray DuBois (third from right). ovarian estrogen for implantation because they have embryonic estrogen. The phenomenon of diapause emphasizes the importance of comparative physiology. In the wallaby, for example, it is pretty fascinating - for months, the embryo will delay implanting and just sit in the uterus. What allows them to survive for so long? What allows their low metabolic rate? How has this strategy changed so that implantation is delayed in a rough environment, but during good times, activation occurs and pregnancy ensues? The beauty is that both the embryo and uterus become quiescent to accommodate this. Does this occur in the human? Nobody knows when the embryo implants - we use hCG as a marker, but implantation actually occurs earlier. Therefore, there is an urgent need to work with different animal models - to determine how we can extend the window of implantation, how to activate delayed implantation, and disengage the receptive from nonreceptive uterus. We have shown this in mice, but investigating this in other animals is essential to understand the complexity - only then can the information be used for clinical applications. Sadly, study of comparative biology has almost disappeared.

What are some of the important research questions related to embryo implantation that should be pursued in the future to positively impact reproductive health?

We still don't understand the molecular landscape for how the uterus transits from the very transient receptive to nonreceptive phase. This has always been very important to me, to figure out how to manipulate the receptive phase in humans, to allow proper timing of embryo transfer. This is a major problem in IVF clinics - the random transfer of embryos - and probably contributes to low success rates.

We also identified some of the embryonic signals that initiate embryo-uterine interactions (Hb-EGF in the mouse), but in other species, we don't know. In humans, we look for hCG, but again, this may not be the first signal - so what initiates attachment? It is possible now with MALDI-mass spec to culture embryos, look for secreted proteins in the spent media, identify which new proteins/ lipid mediators are secreted, attach them to beads, and transfer those beads to the uterus and see what happens.

It will also be important to understand the timing of implantation in humans in a noninvasive way, either through biomarkers or high resolution devices (ultrasound/imaging). When does implantation take place? Without knowing this, we don't really know what is happening in early stages. Lots of early pregnancies probably go unnoticed.

[S. Tranguch: Some of these issues are discussed in excellent reviews from SK's laboratory (Paria et al., 2002; Dey et al., 2004; Wang and Dey 2006; Cha et al., 2012).]

What do you think is your proudest discovery?

Another tough question - this is like asking a parent to pick their favorite child. I enjoyed our finding of the cooperative interaction between preimplantation embryos (Paria and Dey 1990). I believe that this work had huge implications for IVF clinics, who now culture groups of embryos in small culture volume to improve blastocyst formation.

We observed many interesting and fun things: 


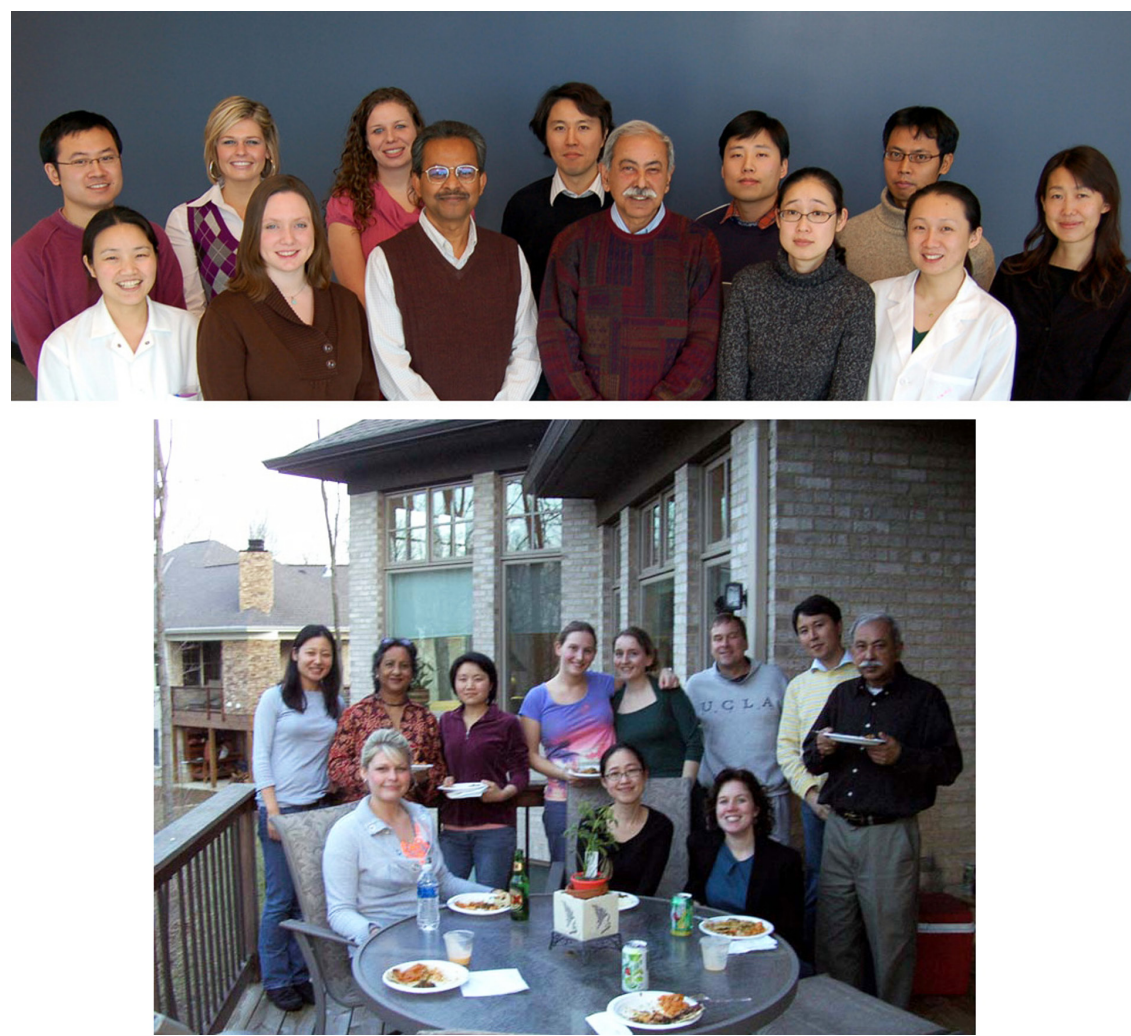

Fig. 5. Arrival in Cincinnati. Faculty and lab members at a summer party in SK's home.
Some big bosses don't even talk to students or reach out to mentor them or learn from them. That's the problem. I always say that I have a wife, but I'm married to my lab. They are my life and my family.

With the NIH's decline in funding, it seems that scientific research will only retain those who can persevere through this rough water. Maybe it's better, who knows... we just have to protect young good minds. As many say that science is not for everybody, and I agree - it's not a 'job', it's a way of life. One other thing which makes me terribly upset is the rhetoric of translational research by many of our leaders. I believe and tell people that whatever your research - whether it is classified as translational, clinical, or basic - do the best science. There is a recent trend in many places to become technologically-driven with little attention to the intellectual endowment. We need both to make meaningful contributions to society and science. [S. Tranguch:When I decided to pursue an editing career out of SK's lab, part of the reason for my decision was that I wasn't sure that I would be able to balance a career with a family and a life. While I still don't have my own family and I certainly miss the research, I also know that I don't have SK's level of devotion to be successful in that career. In listening to SK talk, I realize that I ultimately chose a different lifestyle. At the time, I was nervous to tell SK that I wanted to try becoming an editor of a science journal. The opportunity to join Cell progesterone's memory effect in the uterus; the requirement for progesterone priming and its long-term effects on implantation in the mouse (Huet and Dey, 1990); blastocyst's state of activity determines the window of implantation (Paria et al., 1993); role of Cox2-derived prostaglandins and PPAR $\delta$ in multiple female reproductive processes including implantation (Lim et al., 1997, 1999); the role of cannabinoids/endocannabinoids in early pregnancy (Wang et al., 2004); the identification of HB-EGF as the first indicator of the embryo-uterine interaction (Das et al., 1994); and findings in FKBP52 knockout mice that helped us understand progesterone sensitivity threshold requirements at different stages of pregnancy (Tranguch et al., 2005, 2007); our unexpected finding when we moved from KUMC to Vanderbilt about diet-induced reproductive phenotype changes (Wang et al., 2005); the use of cPLA2 knockout mice to understand the ripple effects throughout pregnancy, i.e., once things go wrong, full complement of pregnancy cannot be maintained (Song et al., 2002); and more recently, our findings of the importance of Msx genes and epithelial cell polarity in pregnancy (Daikoku et al., 2011) and the role of premature decidual senescence in promoting preterm birth (Hirota et al., 2010; Cha et al., 2013). These discoveries were mostly based on our studies in mouse models, but many of them have now shown clinical implications.

What do you think are the biggest challenges to science now?

I was fortunate to always have star graduate students and excellent postdoctoral fellows. Everyone knows that it's not the investigator. If you don't have good people, you can't do much. It has to be a two way interaction to take science to a different level.
Press came right when SK was moving to Cincinnati, and even though I know he would have liked me to stay longer through this transition, he was always so supportive. Reading this interview, the influences of SK's mother and mentors are apparent in his values and actions. His humility is apparent in trying to use this opportunity to recognize the help of others. He has always been supportive, encouraging, and relentless in pushing others to be better. Regardless of him not taking credit, he is a major reason for my success - he is the reason I work hard, he is the reason my career has evolved to support research programs and research investigators, and of course, he is the reason I still wake up 'early' on Sunday mornings to chat.]

\section{References}

CHA J, BARTOS A, EGASHIRA M, HARAGUCHI H, SAITO-FUJITA T, LEISHMAN E, BRADSHAW H, DEY SK, and HIROTA Y (2013). Combinatory approaches prevent preterm birth profoundly exacerbated by gene-environment interactions. $J$ Clin Invest 123:4063-4075. doi:10.1172/JCI70098.

CHA J, SUN X, and DEY SK (2012). Mechanisms of implantation: strategies for successful pregnancy. Nat Med 18: 1754-1767.

DAIKOKU T, CHA J, SUN X, TRANGUCH S, XIE H, FUJITA T, HIROTA Y, LYDON J, DEMAYO F, MAXSON R, and DEY SK (2011). Conditional deletion of MSX homeobox genes in the uterus inhibits blastocyst implantation by altering uterine receptivity. Developmental Cell 21: 1014-1025

DAS SK, WANG XN, PARIA BC, DAMM D, ABRAHAM JA, KLAGSBRUN M, ANDREWS GK and DEY SK (1994). Heparinbinding EGFlike growth factor gene is induced in the mouse uterus temporally by the blastocyst solely at the site of its apposition: A possible ligand for interaction with blastocyst EGFreceptor in implantation. Development 120: 10711083.

DEY SK, LIM H, DAS SK, REESE J, PARIA BC, DAIKOKU T, and WANG H (2004). 


\section{S. Tranguch and S.K. Dey}

Molecular cues to implantation. Endocr Rev 25: 341-373.

DEY SK, SEN GUPTAJ, and DEB C (1973). Histochemical studies on the Leydig-cellleucine aminopeptidase activity in the guinea-pig testis. J Reprod Fert34:475-479.

DEY SK, VILLANUEVA C, and ABDOU NI (1979) Histamine receptors on rabbit blastocyst and endometrial cell membranes. Nature 278: 648-649.

HIROTA Y, DAIKOKU T, TRANGUCH S, XIE H, BRADSHAW HB, and DEY SK (2010). Uterine-specific p53 deficiency confers premature uterine senescence and promotes preterm birth in mice. J Clin Invest 120: 803-815.

HUET YM and DEY SK (1990). Requirement for progesterone priming and its longterm effects on implantation in the mouse. Proc Soc Exp Biol Med 193: 259-263.

LIM H, GUPTA RA, MA WG, PARIA BC, MOLLER DE, MORROW, JD, DUBOIS RN, TRZASKOS JM and DEY SK (1999). Cyclo-oxygenase-2-derived prostacyclin mediates embryo implantation in the mouse via PPARס. Gene Dev13: 1561-1574.

LIM H, PARIA BC, DAS SK, DINCHUK JE, LANGENBACH R, TRZASKOS JM and DEYSK (1997). Multiple female reproductive failures in cyclooxygenase 2-deficient mice. Cell 91: 197-208.

MATSUMOTO H, ZHAO X, DAS SK, HOGAN BL, and DEY SK (2002). Indian hedgehog as a progesterone-responsive factor mediating epithelial-mesenchymal interactions in the mouse uterus. Dev Biol 245: 280-290.

MONDSCHEIN JS, HERSEY RM, DEY SK, DAVIS DL, and WEISZ J (1985). Catechol estrogen formation by pig blastocysts during the preimplantation period: biochemical characterization of estrogen-2/4-hydroxylase and correlation with aromatase activity. Endocrinology 117: 2339-2346.

PARIA BC and DEY SK (1990). Preimplantation embryo development in vitro: cooperative interactions among embryos and role of growth factors. Proc Natl Acad Sci USA 87: 4756-4760.

PARIA BC, HUETHUDSON YM and DEY SK (1993). Blastocyst's state of activity determines the "window" of implantation in the receptive mouse uterus. Proc Natl Acad Sci USA 90: 1015910162
PARIABC, MAW, TAN J, RAJAS, DAS SK, DEY SK, and HOGAN BL (2001). Cellular and molecular responses of the uterus to embryo implantation can be elicited by locally applied growth factors. Proc Natl Acad Sci USA 98: 1047-1052.

PARIA BC, REESE J, DAS SK, and DEY SK (2002) Deciphering the cross-talk of implantation: advances and challenges. Science 296: 2185-2188.

REESE J, DAS SK, PARIA BC, LIM H, SONG H, MATSUMOTO HM, KNUDTSON KL, DUBOIS RN, and DEY SK (2001). Global gene expression analysis to identify molecular markers of uterine receptivity and embryo implantation. $J$ Biol Chem 276: 44137-44145.

SEN GUPTA J, DEY SK, and DEB C (1973). Histochemical studies on leucine aminopeptidase activity in the rat uterus. $J$ Reprod Fert 34: 467-473.

SONG H, LIM H, PARIABC, MATSUMOTOH, SWIFT LL, MORROWJD, BONVENTRE $J V$, and DEY SK (2002). Cytosolic phospholipase $A_{2} \alpha$ is crucial for "on-time" embryo implantation that directs subsequent development. Development 129:2879-2889.

TRANGUCH S, CHEUNG-FLYNN J, DAIKOKU T, PRAPAPANICH V, COX MB, XIE H, WANG H, DAS SK, SMITH DF and Dey SK (2005). Cochaperone immunophilin FKBP52 is critical to uterine receptivity for embryo implantation. Proc Natl Acad Sci USA 102: 14326-14331.

TRANGUCHS, WANG H, DAIKOKU T, XIE H, SMITHD and DEY SK (2007). FKBP52 deficiency-conferred uterine progesterone resistance is genetic background and pregnancy stage specific. J Clin Invest 117: 1824-1834.

WANG H and DEY SK (2006) Roadmap to embryo implantation: clues from mouse models. Nat Rev Genet 7: 185-199.

WANG H, GUO Y, WANG D, KINGSLEY PJ, MARNETT LJ, DAS SK, DUBOIS RN and DEY SK (2004). Aberrant cannabinoid signaling impairs oviductal transport of embryos. Nat Med 10: 1074-1080.

WANG H, TRANGUCH S, XIE H, HANLEY G, DAS SK, and DEY SK (2005). Variation in commercial rodent diets induces disparate molecular and physiological changes in the mouse uterus. Proc Natl Acad Sci USA 102: 9960-9965. 


\section{Further Related Reading, published previously in the Int. J. Dev. Biol.}

Epithelial cell polarity and embryo implantation in mammals

$\mathrm{M}$ Thie, $\mathrm{P}$ Fuchs and $\mathrm{H}$ W Denker

Int. J. Dev. Biol. (1996) 40: 389-393

http://www.intjdevbiol.com/web/paper/8735953

Embryo culture, stem cells and experimental modification of the embryonic genome. An interview with Professor Ralph Brinster Juan Aréchaga

Int. J. Dev. Biol. (1998) 42: 861-878

http://www.intjdevbiol.com/web/paper/9853816

Early mammalian embryo: my love. An interview with Andrzej K. Tarkowski Marek Maleszewski and Andrzej K. Tarkowski

Int. J. Dev. Biol. (2008) 52: 163-169

http://dx.doi.org/10.1387/ijdb.072377mm

Trophoblast phagocytic program: roles in different placental systems

Estela Bevilacqua, Mara-Sandra Hoshida, Andrea Amarante-Paffaro, Andrea Albieri-Borges and Sara Zago-Gomes

Int. J. Dev. Biol. (2010) 54: 495-505

http://dx.doi.org/10.1387/ijdb.082761eb

Inductive tissue interactions. An interview with Chancellor Lauri Saxén

Eero Lehtonen

Int. J. Dev. Biol. (1999) 43: 371-376

http://www.intjdevbiol.com/web/paper/10535312

5 yr ISI Impact Factor $(2011)=2.959$
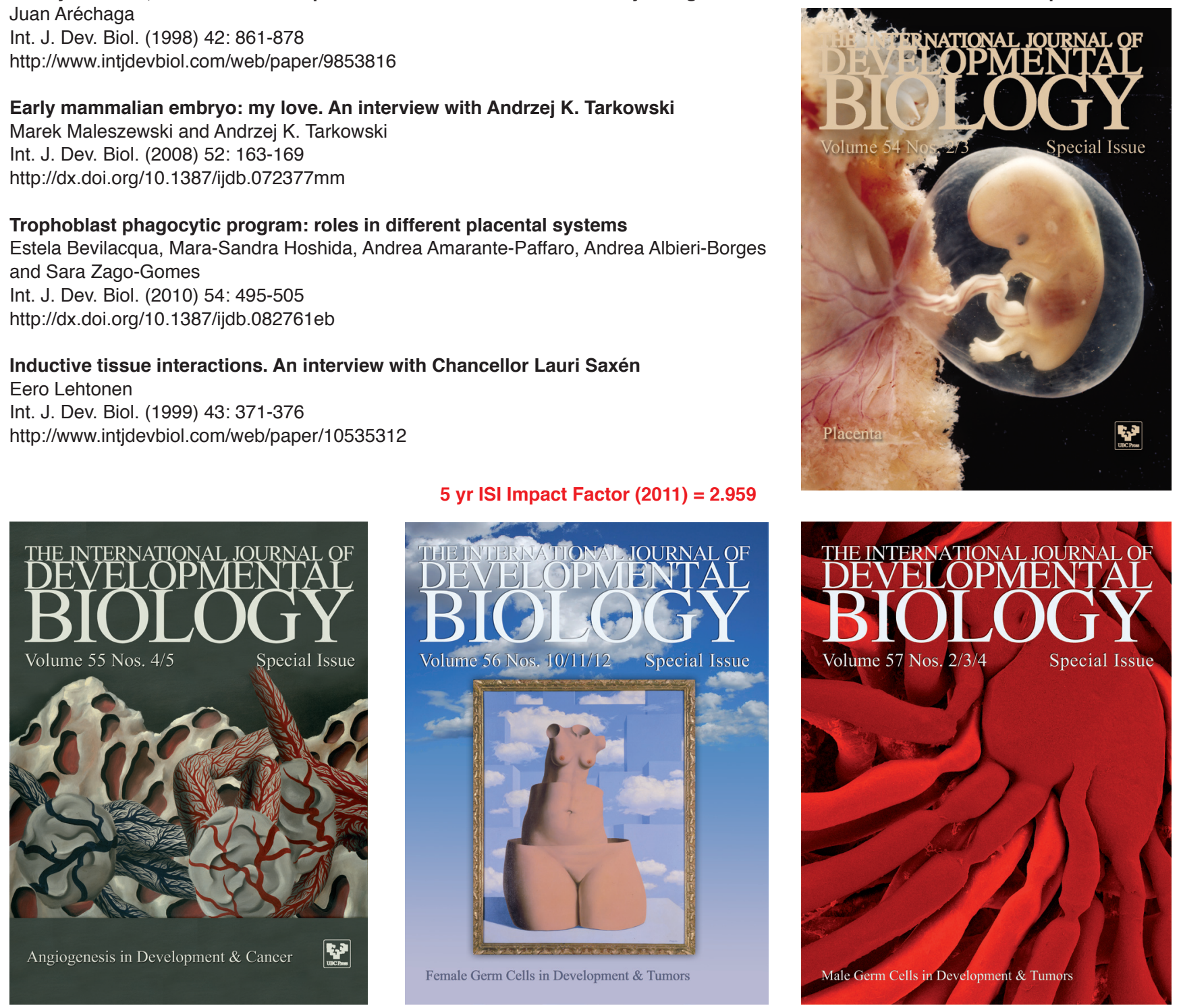